\title{
Comparing 5-year Outcomes of Aorta-Coronary Bypass Surgery and Percutaneous Coronary Intervention Performed with New-Generation Drug-Eluting Stents in Non-Diabetic Patients with Multivessel Acute Coronary Syndrome Patients and Intermediate Syntax Score
}

\author{
Orta Dereceli Syntax Skoruna Sahip Diabetik Olmayan ve Coklu Damar \\ Hastalığı Bulunan Akut Koroner Șendromlu Hastalarında Aorta-Koroner \\ By-pass Cerrahisi ile Yeni Kuşak İlaç Kaplı Stent ile Yapılan Perkütan \\ Koroner Girişimin 5 Yıllık Sonuçlarının Karşılaştırılması
}

\begin{abstract}
Firdovsi IBRAHIMOV®, Yusuf YILMAZ๑, Isfandiyar ISMAYILOV®, Kamran MUSAYEV ${ }^{\circ}$, Ogtay (OKTAY) MUSAYEV® Shahana ALASGARLI ${ }^{\circledR}$, Shafa SHAHBAZOVA®, Mehriban ISGENDEROVA®, Tofig JAHANGIROV®

Ethics Committee Approval: This study was approved by the Ethical Committee of Azerbaijan Medical University, 29 November 2019, 2019/010.

Conflict of interest: The authors declare that they have no conflict of interest.

Funding: None.

Informed Consent: Informed consent was taken from the parents of the patients enrolled in this study.

Cite as: İbrahimov F, Yllmaz Y, İsmayilov I, et al. Comparing 5-year outcomes of aortaCite as: Ibrahimov F, Yilmaz Y, ismayilov I, et al. Comparing 5-year outcomes of aorta-
coronary bypass surgery and percutaneous coronary intervention with new-generation drug-eluting stents in non-diabetic and multivessel acute coronary syndrome patients with intermediate syntax score. Medeniyet Med J. 2020;35:121-7.
\end{abstract}

\begin{abstract}
Objective: Our main objective is to determine the difference between patients undergoing $C A B C$ and $P C l$ with new-generation drug-eluting stents who were non-diabetic during the course of a multivessel acute coronary syndrome (ACS) and intermediate SYNTAX score.

Methods: Between 2012 and 2014, we retrospectively evaluated 1011 non-diabetic patients with ACS in a single center. The patients were followed up up to 5-years. All-cause mortality, cardiac death, myocardial infarction, stroke, revascularization and stent thrombosis were recorded accordingly. Results: A total of $516(51 \%)$ patients were included in the $P C l$ group and 495 patients (49\%) in the $C A B G$ group. Stroke occurrence ( $P C l$ group: $0.8 \%$, and $C A B G$ group: $2.6 \%, p=0.022$ ), requirement for recurrent revascularizations (PCI group: $13.6 \%$, and CABG group: $8.1 \%, p=0.005$ ) and the MACE percentage ( $P C l$ group: $20.3 \%$, and CABG group: $14.5 \%, p=0.015)$ were statistically significant between two groups. However, there was no statistical significance difference between two groups in terms of primary endpoints including death, $M I$, and stroke (PCI group: $10.9 \%$, and CABG group: $8.3 \%, p=0.165$ ) and all-cause mortality $P C l$ group $6.2 \%$, and $C A B G$ group: $4.7 \%, p=0.298$ )

Conclusion: There was no difference in all-cause mortality and myocardial infarction between the $P C I$ and the $C A B G$ groups during 5-year follow-up. The frequency of repeated revascularizations was lower in the $C A B G$ group than the PCI group. In contrast, the stroke rates were higher in the CABG group.
\end{abstract}

Keywords: PCI; CABG; non-diabetic; stent; mortality; acute coronary syndrome

Öz

Amaç: Araştırmadaki temel amacımız, çok damarlı akut koroner sendromu (ACS) ve ara değer SYNTAX puanı bulunan süreçte diyabetik olmayan CABG ve (yeni nesil ilaç salınımlı stentli) $P C l$ geçiren hastalar arasındaki farkı saptamaktır.

Yöntem: 2012-2014 arasında tek merkezde, ACS'li 1011 diyabetik olmayan hastayı retrospektif olarak değerlendirdik. Hastaların takibi 5 yıla kadar yapılmıştır. Tüm nedenlere bağlı ölüm, kardiyak ölüm, miyokard enfarktüsü, inme, revaskülarizasyon ve stent trombozu buna göre kaydedilmiştir. Bulgular: 516 (\%51) hasta PCI grubuna, 495 hasta (\%49) CABG grubuna alınmıstır. Inme oluşumu (PCl grubunda $\% 0,8$ ve CABG grubunda $\% 2,6, p=0,022$ ), tekrarlanan revaskülarizasyon gereksinimi ( $P C l$ grubunda \%13,6 ve CABG grubunda \%8,1, $p=0,005$ ) ve $M A C E$ yüzdeleri (PCl grubunda \%20 3. CABG grubunda \%14,5, $p=0,015$ ) iki grup arasında istatistiksel olarak anlamlı derecede farklı bulunmuştur. Öte yandan, ölüm, MI ve inme ( $P C l$ grubunda \%10,9 ve CABG grubunda \%8,3, $p=0,165$ ) ve tüm nedenlere bağlı mortalite ( $P C l$ grubunda \%6,2, CABG grubunda \%4,7, $p=0,298$ ) dahil olmak üzere birincil sonlanım noktaları arasında iki grup karşılaştııılı̆̆ında istatistiksel açıdan anlamlılı fark yoktur.

Sonuc: Bes yıllık takip sırasında tüm nedenlere bağlı mortalite ve miyokart enfarktüsü açısından PCI ile $C A B G$ grupları arasında anlamlı fark bulunmamıştır. Tekrarlanan revaskülarizasyon ise CABG grubunda $P C l$ grubundan daha düşüktür. Bunun aksine, inme oranları CABG grubunda daha yüksek çıkmıştır.

Anahtar kelimeler: PCI; CABG; diyabetik olmayan; stent; mortalite; akut koroner sendrom
Received: 26 February 2020

Accepted: 2 May 2020

Online First: 30 June 2020

Corresponding Author:

F. ibrahimov

ORCID: 0000-0003-1027-6337 Azerbaijan Medical University,

Department of Cardiology, Baku, Azerbaijan

firdovsiibrahimov@gmail.com

I. İsmayilov

ORCID: 0000-0003-1163-0043

Azerbaijan Medical University, Department of Cardiology, Baku, Azerbaijan

Y. Yilmaz

ORCID: 0000-0002-6676-2740

Istanbul Medeniyet University, Department of Cardiology, Istanbul, Turkey

K. Musayev

ORCID: 0000-0002-0020-2118

Central Hospital of Baku, Department of Cardiovascular Surgery, Baku, Azerbaijan

O. (Oktay) Musayev ORCID: 0000-0001-6859-5088 ORCID: 0000-0002-3638-6502 ORCID: 0000-0002-6695-1584 ORCID: 0000-0001-5051-2678

Central Hospital of Baku,

Department of Cardiology, Baku, Azerbaijan

T. Jahangirov

ORCID: 0000-0003-3445-7191

l. Abdullayev's Research Institute of Cardiology,

Department of Cardiology, Baku, Azerbaijan

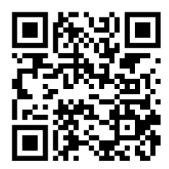




\section{INTRODUCTION}

Despite advances in therapeutic, surgical and percutaneous invasive interventions, coronary artery disease (CAD) remains the leading cause of death in both Western and developing countries. The optimal approach to revascularization in patients with multi-vessel coronary artery disease has been the main focus of randomized clinical trials performed over the past 30 years. American College of Cardiology Foundation/American Heart Association ${ }^{1,2}$ and the European Cardiology Association/European Cardio-Thoracic Surgery Association ${ }^{3}$ guidelines provide guidance for decision-making in patients with multi-vessel diseases. In both guidelines, when the surgical risk is acceptable, it is recommended to prefer aortocoronary shunt rather than percutaneous coronary intervention in individuals with multivessel coronary artery disease accompanied by diabetes. This is especially true in cases when the anastomosis of the left internal mammary artery to the left anterior descending artery is possible.

However, there are disagreements over decision of the optimal revascularization method for patients with multivessel disease without diabetes, the death rate is undoubtedly the key point while choosing a treatment strategy. Furthermore, most of the randomized studies do not have sufficient statistical power to clarify the difference in mortality rates between the coronary artery bypass graft surgery (CABG) and the percutaneous coronary intervention ( $\mathrm{PCI})$. The patient information resource in these studies can be proposed to increase statistical power and provide sufficient time to analyze these problems ${ }^{4}$.

Comparisons of CABG with $\mathrm{PCI}$ have shown results in favor of surgery in the studies of the firstgeneration drug-eluting stents. In these studies, this was more evident in diabetic patients.

New generation drug-eluting stents had a lower metal load and more sensitive citrate compounds compared to the first-generation drug-eluting stents; citrate is a more uniform and bio-degradable polymer in the new generation drug-eluting stents which also have less thrombogenic and inflammatory properties ${ }^{5,6}$. For this reason, we have decided to investigate the effects of new-generation drug-eluting stents on non-diabetic patients with multi-vessel acute coronary syndromes.

\section{MATERIALS and METHODS}

This study evaluated the 1011 consecutive nondiabetic patients with unstable angina pectoris (USAP) and non-ST segment elevation myocardial infarction (NSTEMI) who had undergone coronary revascularization therapy in two parts. The first part was a retrospective evaluation and the second part was a prospective follow-up by the same physician during the study period between the years 2012 and 2014 .

Patients were included in the study; if (I) they had been admitted with an ACS (USAP or NSTE$\mathrm{MI})$ and had multi-vessel coronary artery disease (CAD) involving at least two stenotic ( $\geq 70 \%)$ epicardial coronary arteries (II) had Non-DM, (III) had undergone isolated PCI or CABG, and (IV) had an intermediate Syntax score. Patients with left main $\mathrm{CAD}$, history of cardiac surgery, $\mathrm{PCI}$, cardiogenic shock, acute myocardial infarction (MI), new STElevation Myocardial Infarction (STEMI), and elevated creatinine ( $>2 \mathrm{md} / \mathrm{dl}$ ) were all excluded. USAP was defined as discomfort on the chest or acceleration of previous angina which occurred during a long-lasting exertion. ST-T changes were the supporting indicators of USAP, in that group of patient's normal troponin levels also supported the diagnosis of USAP and NSTEMI is defined as acute chest pain without persistent ST-segment elevation, and an increase and/or decrease of cardiac troponin, with at least one value above the $99^{\text {th }}$ percentile of the upper reference limit ${ }^{7}$.

The clinical characteristics, laboratory parameters, and medical history were obtained from the pa- 
F Ibrahimov et al. Comparing 5-year Outcomes of Aorta-Coronary Bypass Surgery and Percutaneous Coronary Intervention Performed with NewGeneration Drug-Eluting Stents in Non-Diabetic Patients with Multivessel Acute Coronary Syndrome Patients and Intermediate Syntax Score

tient charts recorded at the time of index hospitalization. Systemic blood pressure levels exceeding 140/90 $\mathrm{mmHg}$ with repeated measurements or treatment with antihypertensive medication were defined as hypertension. Non-DM was diagnosed as fasting blood glucose $<126 \mathrm{mg} / \mathrm{dL}$. Baseline total cholesterol level $>200 \mathrm{mg} / \mathrm{dL}$ or current treatment with statins and/or lipid-lowering agents was defined as hypercholesterolemia. Current smokers were those with regular smoking within the previous 6 months. Syntax score was calculated according to the SYNTAX score algorithm ${ }^{8}$.

Standard techniques were used for PCI and newgeneration drug-eluting stents were implanted in the PCI group. All patients used clopidogrel as P2Y12 inhibitor and acetylsalicylic acid (ASA) as dual antiplatelet therapy strategy for a minimum 12 months after stent implantation. Patients were evaluated with echocardiography by experienced echocardiographers according to the European Association of Echocardiography/American Society of Echocardiography guidelines?

\section{Follow-up and outcomes}

Patients were followed up for 30 days, 1 year, and 5 years. Follow-up information was collected either via phone contact or by face-to-face hospital visits. All clinical events, such as all-cause mortality, cardiac death, MI, stroke, revascularization, and stent thrombosis were recorded accordingly. Both short-term (within 30 days) and long-term (median 60 months) outcomes were evaluated. Short-term and long-term all-cause mortality was the primary endpoint of the study and major adverse cardiovascular events (MACE) that covered all-cause mortality, MI, stroke, and repeated revascularization were the secondary endpoints.

The definition of MI was made as spontaneous, PCI-related and CABG-related. The indicators of MI were new or pathologic $Q$ wave and/or serum troponin level elevations during the 5-year follow-up. We investigated all causes of death and divided them into two groups as cardiac and noncardiac causes. Cancer-related death was defined as a separate group. Cerebrovascular events were defined as acute conditions lasting for at least 24 hours with a permanent loss of function and brain damage. All cerebrovascular events were confirmed by a neurologist and imaging methods.

\section{Statistics}

All analyses were performed by SPSS 18.0 package program. Continuous variables were expressed as mean and SD values, and categorical variables as percentages. Chi-square and independent samples t-test were used for statistical analysis. Differences in long-term events were evaluated by the Kaplan-Meier curve with the log-rank test. A p-value below 0.05 was considered statistically significant.

\section{RESULTS}

A total of 1011 non-DM patients out of a total 1643 cases with ACS were included in the study. The PCI group included 516 (51\%), and CABG group 495 (49\%) patients. The characteristics of the groups are shown in Table 1 . There were no significant differences between the groups in terms of age, gender, the prevalence of hyper-

Table 1. Demographic, laboratory and clinical characteristics of the study groups.

\begin{tabular}{|c|c|c|c|}
\hline & $\begin{array}{l}\text { CABG } \\
n=495(\% 49)\end{array}$ & $\begin{array}{l}\text { PCI } \\
n=516(\% 49)\end{array}$ & $\mathbf{p}$ \\
\hline Age, y $($ mean $\pm S D)$ & $56,6( \pm 8,3)$ & $55,6( \pm 9,1)$ & 0.954 \\
\hline Women, n (\%) & $62(\% 12,5)$ & $49(\% 9,5)$ & 0.124 \\
\hline $\begin{array}{l}\text { Hypercholesterolemia, } \\
\text { n (\%) }\end{array}$ & $308(\% 62,2)$ & $319(\% 61,8)$ & 0.896 \\
\hline Currentsmoker, n (\%) & $114(\% 23)$ & $117(\% 22,6)$ & 0.798 \\
\hline Previousstroke, n (\%) & $10(\% 0,8)$ & $6(\% 1,2)$ & 0.569 \\
\hline HT, n (\%) & $184(\% 35.7)$ & $329(\% 66.5)$ & 0.001 \\
\hline $\begin{array}{l}\text { Peripheralvasculardisease, } \\
\mathrm{n}(\%)\end{array}$ & $45(\% 9,1)$ & $12(\% 2,5)$ & 0.045 \\
\hline $\begin{array}{l}\text { CKD (creatinine } \\
150-200 \mathrm{mg} / \mathrm{dl}), \mathrm{n}(\%)\end{array}$ & $11(\% 2.1)$ & $18(\% 3.6)$ & 0.152 \\
\hline LVEF $<\% 40, \mathrm{n}(\%)$ & $168(\% 32.6)$ & $134(\% 27.1)$ & 0.057 \\
\hline
\end{tabular}

PCI: percutaneous coronary intervention, CABG: coronary artery bypass grafting surgery, USAP: unstable angina pectoris, HT: hypertension, CKD: chronic kidney disease, LVEF: left ventricle ejection fraction. 
cholesterolemia, stroke, chronic kidney disease, left ventricular ejection fraction, current smoking status, and Syntax score. Patients with hypertension were significantly higher in the CABG group than the PCI group.

The left internal mammary artery (LIMA) was used in $95 \%$ of patients undergoing CABG. Median follow-up time was 60.7 months (interquartile range: 47-71 months).

All-cause mortality during a 5-year-follow-up period was observed in 32 patients $(6.2 \%)$ in the $\mathrm{PCl}$ group, and in 23 patients $(4.7 \%)$ in the CABG group $(p=0.298)$ without any significant intergroup difference. Furthermore, rates of $\mathrm{MI}$ (PCI group 7.4\%, and CABG group: $4.6 \% \mathrm{p}=0.07$ ) and primary endpoint during 5-years ( $\mathrm{PCI}$ group: $10.9 \%$, and $C A B G$ group $8.3 \%, p=0.165$ ) were not statistically significantly different between two groups.

Kaplan-Meier Survival Analysis also showed that there was no significant difference between $\mathrm{PCI}$

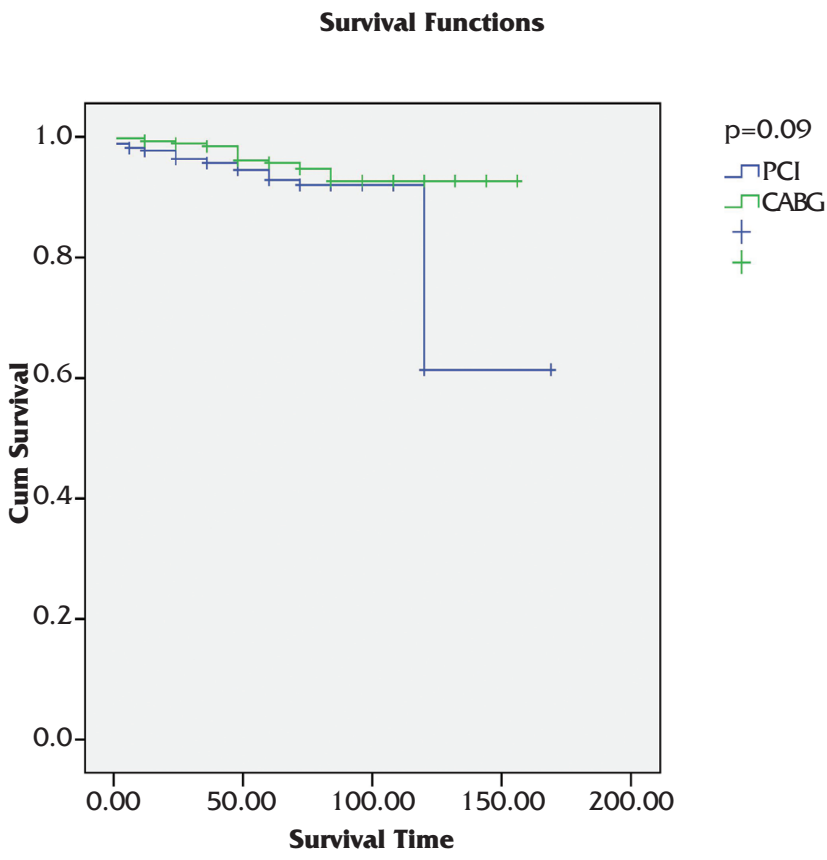

Figure 1. Kaplan-Meier Survival Analysis also shows that there is no difference between PCI (in the use of newgeneration drug eluting stents) and CABG during 5-year observation. and $C A B G$ groups in terms of the use of newgeneration drug-eluting stents during 5-years of observation ( $p=0.09)$ (Figure 1).

The rates of requirement for repeated revascularization, and stroke were statistically significantly different between $\mathrm{PCl}(13.6 \%$ vs $0.8 \%)$, and CABG $(8.1 \%$ vs $2.6 \%)$ groups $(p=0.005$; and 0.022 , respectively).

The MACE percentage in the PCI group (20.3\%) was statistically significantly higher in the CABG group (14.5\%) ( $p=0.015)$ (Table 2$)$.

Table 2. Estimates of major adverse cardiovascular and cerebrovascular events at 5-year follow-up after the procedure.

\begin{tabular}{llll}
\hline & \multicolumn{2}{c}{ 5-year follow-up, n (\%) } \\
\cline { 2 - 3 } EVENT & PCI & CABG & P value \\
\hline MACE & $105(\% 20.3)$ & $72(\% 14.5)$ & 0.015 \\
Death & $31(\% 6.2)$ & $22(\% 4.7)$ & 0.298 \\
Cardiac mortality & $18(\% 58.1)$ & $16(\% 66.7)$ & 0.515 \\
Myocardialinfarction & $38(7.4 \%)$ & $23(4.6 \%)$ & 0.070 \\
Stroke & $4(\% 0.8)$ & $13(\% 2.6)$ & 0.022 \\
Repeated revascularization & $70(\% 13.6)$ & $40(\% 8.1)$ & 0.005 \\
Primary endpoint & $56(10.9 \%)$ & $41(8.3 \%)$ & 0.165 \\
\end{tabular}

PCI: percutaneous coronary intervention, CABG: coronary artery bypass grafting surgery, MACE: Major Adverse Cardiac Events.

When the long-term mortality rates were evaluated, there were only 32 deaths in the $\mathrm{PCI}$ group. These deaths were related to cardiac $(n=18$; $58.1 \%)$, and extracardiac (41.9\%) etiologies (cancer, etc). There were 23 deaths in the CABG group. While $66.7 \%$ of these deaths were due to cardiac causes (15 deaths), and $33.3 \%$ of them to extra-cardiac causes (cancer, etc.) $(p=0.515)$.

\section{DISCUSSION}

With this study, we revealed that in non-diabetic patients with ACS and intermediate SYNTAX scores, performing $\mathrm{CABG}$ instead of $\mathrm{PCI}$ decreases the requirement of repeated $\mathrm{PCI}$ and MACE but exposes the patients to an increased risk of a new stroke. On the other hand, a significant difference 
F Ibrahimov et al. Comparing 5-year Outcomes of Aorta-Coronary Bypass Surgery and Percutaneous Coronary Intervention Performed with NewGeneration Drug-Eluting Stents in Non-Diabetic Patients with Multivessel Acute Coronary Syndrome Patients and Intermediate Syntax Score

was not found between performing PCI or CABG in this group of patients, in terms of all-cause mortality, re-infarction, and primary endpoints.

In a study conducted by Serruys and his colleagues, it was seen that in patients with moderate or advanced SYNTAX scores CABG induced an important decrease in primary endpoints compared with PCI. In the SYNTAX study, $75 \%$ of patients were nondiabetic ${ }^{8}$.

The long-term benefits of CABG are due to its reduction in the rates of repeated revascularization. Early results of this study were included in the ACCF/AHA and ESC/EACTS clinical recommendations. However, the biggest disadvantage of the SYNTAX research today is the use of firstgeneration drug-eluting stents. It is seen that these stents are far inferior when compared to the new generation stents in terms of repeated revascularization, in-stent thrombosis and myocardial infarction ${ }^{10}$.

In contrast to the SYNTAX study, in our study, no differences were found in the primary endpoints between the two groups $(p=0.165)$ thanks to the use of new-generation drug-eluting stents.

Unlike the first-generation drug-eluting stents, the polymer portion of these stents is very thin and completely absorbable within the 6 months of implantation, which translates into a significant reduction of $\mathrm{MI}$ and death both in the short and long-term follow-up after the procedure ${ }^{11}$.

This advantage gained from the new generation drug-eluting stents has also been revealed in the BEST trial. In that study, which involved 880 patients with multi-vessel coronary artery disease, $60 \%$ of patients were nondiabetic. Again in that study, there were no differences between the two groups in terms of the primary endpoints. However, at 4.6 years of follow-up, it was revealed that $C A B G$ was superior in terms of reducing the requirement for repeated revascularization ${ }^{12}$.
However, neither the SYNTAX nor the BEST research has sufficient statistical power to predict mortality in nondiabetic patients. To address this problem, Chang et al. ${ }^{13}$ examined the metaanalysis of the SYNTAX and the BEST studies in nondiabetic patients. In this meta-analysis, that included 1275 patients, the mean follow-up time was 61 months. In this study, CABG was superior in reducing the rates of all-cause mortality $(p=0.039)$, myocardial infarction $(p<0.001)$, and repeated revascularization $(p<0.001)$. The 5-year stroke rates were similar to the SYNTAX study $(p=0.714)$.

However, there were some shortcomings in the study by Chang et al. The most important of these disadvantages was the fact that most patients were transferred from the SYNTAX study, where the first-generation drug-eluting stents were used. It was known that the first-generation drug-eluting stents caused more serious complications than the second or third-generation drug-eluting stents ${ }^{14-}$ ${ }^{16}$. In this regard, our study has more profound reflections on the differences imposed by the use of new-generation drug-eluting stents. Unlike other studies, in our study, there were no differences in terms of all-cause mortality $(p=0.298)$, myocardial infarction $(p=0.07)$, and primary endpoints between the two groups during the 5-year follow-up. In our study, while CABG was superior concerning reduction on repeated revascularization rates $(p=0.005)$, it remained inferior to $\mathrm{PCI}$ in terms of decreasing stroke incidents $(p=0.022)$. The MACE percentage seen in nondiabetic patients favoring $C A B G$ was secondary to repeated revascularizations $(p=0.015)$. Unlike other studies, the difference we achieved in our study stemmed from the use of new-generation drug-eluting stents.

The ASCERT study demonstrated similar results in a 1-year mortality rate between the two groups (risk ratio: 0.95 ; $95 \% \mathrm{CI}$ : 0.90 to 1.00 ). However, the 4-year mortality rate was lower in the CABG group. This difference was the same in the nondiabetic group ${ }^{17}$. 
Athappan G et al. ${ }^{18}$ found that postoperative stroke was a serious complication increasing the rates of mortality and morbidity. In this study, it was revealed that early stroke was significantly lower in the PTCA group compared to the CABG group. However, in the long-term, the stroke rates between the two groups became similar.

In our study, stroke in non-diabetic patients was more common in the CABG group compared to the PTCA group. This was even more pronounced in the CABG group, particularly in the early postoperative periods ${ }^{1}$. The difference in rates of stroke between studies is more likely to result from research design, treatment strategies, and timing $^{19-21}$.

This similar difference was also revealed in the 2.9-year follow-up of another study using everolimus-eluting stents ${ }^{22}$. Looking at all these discussions, it can be seen that in patients with multivessel coronary artery disease with intermediate SYNTAX scores, PCI is not inferior to the CABG. As a result, PTCA can be considered as an alternative in this group of patients.

\section{Study limitations}

Our study has several limitations. First it was a single- center study. Besides, if there were many more patients, we could have achieved more comprehensive results, and we might also be able to evaluate subgroups. New p2y12 inhibitors were not used in this study because the only accessible p2y12 inhibitor was clopidogrel in our country. Lack of randomization to either PCI or CABG groups might be accepted as a limitation. However, retrospective enrollment of our patients is a strength of the study as it represents the reallife clinical settings.

\section{CONCLUSION}

This real-world setting of nondiabetic patients showed that there was no difference in all-cause mortality and $\mathrm{MI}$ between the PCI and the CABG groups during the 5-year follow-up period. Repeated revascularizations were more frequently performed in the $\mathrm{PCI}$ group than in the CABG group. In contrast, the stroke rates were higher in the CABG group.

\section{REFERENCES}

1. Fihn SD, Gardin JM, Abrams J, et al. 2012 ACCF/AHA/ ACP/AATS/PCNA/SCAI/STS guideline for the diagnosis and management of patients with stable ischemic heart disease: executive summary: a report of the American College of Cardiology Foundation/American Heart Association task force on practice guidelines, and the American College of Physicians, American Association for Thoracic Surgery, Preventive Cardiovascular Nurses Association, Society for Cardiovascular Angiography and Interventions, and Society of Thoracic Surgeons [published correction appears in Circulation. 2014 Apr 22;129(16):e462. Circulation. 2012;126:3097-137. [CrossRef]

2. Fihn SD, Blankenship JC, Alexander KP, et al. 2014 ACC/ AHA/AATS/PCNA/SCAI/STS focused update of the guideline for the diagnosis and management of patients with stable ischemic heart disease: a report of the American College of Cardiology/American Heart Association Task Force on Practice Guidelines, and the American Association for Thoracic Surgery, Preventive Cardiovascular Nurses Association, Society for Cardiovascular Angiography and Interventions, and Society of Thoracic Surgeons. J Am Coll Cardiol. 2014;64:1929-49. [CrossRef]

3. Authors/Task Force members, Windecker S, Kolh P, et al. 2014 ESC/EACTS Guidelines on myocardial revascularization: The Task Force on Myocardial Revascularization of the European Society of Cardiology (ESC) and the European Association for Cardio-Thoracic Surgery (EACTS) Developed with the special contribution of the European Association of Percutaneous Cardiovascular Interventions (EAPCI). Eur Heart J. 2014;35:2541-619. [CrossRef]

4. Riley RD, Lambert PC, Abo-Zaid G. Meta-analysis of individual participant data: rationale, conduct, and reporting. BMJ. 2010;340:c221. Published 2010 Feb 5. [CrossRef]

5. Kolandaivelu K, Swaminathan R, Gibson WJ, et al. Stent thrombogenicity early in high-risk interventional settings is driven by stent design and deployment and protected by polymer-drug coatings. Circulation. 2011;123:1400-9. [CrossRef]

6. Sipahi I, Akay MH, Dagdelen S, Blitz A, Alhan C. Coronary artery bypass grafting vs percutaneous coronary intervention and long-term mortality and morbidity in multivessel disease: meta-analysis of randomized clinical trials of the arterial grafting and stenting era. JAMA Intern Med. 2014;174:223-30. [CrossRef]

7. Giugliano RP. Non-ST Elevation Acute Coronary Syndromes. In: Bonow RO, Mann DL,Tomaselli GF, editors. Braunwald's Heart Disease: A Textbook of Cardiovascular Medicine. $11^{\text {th }}$ ed. USA: Saunders/ Elsevier, 2018. $\mathrm{p}$ $1181-1208$.

8. Serruys PW, Morice MC, Kappetein AP, et al. Percutaneous coronary intervention versus coronary-artery bypass grafting for severe coronary artery disease [published correction appears in N Engl J Med. 2013 Feb 7;368:584. 
F Ibrahimov et al. Comparing 5-year Outcomes of Aorta-Coronary Bypass Surgery and Percutaneous Coronary Intervention Performed with NewGeneration Drug-Eluting Stents in Non-Diabetic Patients with Multivessel Acute Coronary Syndrome Patients and Intermediate Syntax Score

N Engl J Med. 2009;360:961-72. [CrossRef]

9. Lang RM, Badano LP, Mor-Avi V, et al. Recommendations for cardiac chamber quantification by echocardiography in adults: an update from the American Society of Echocardiography and the European Association of Cardiovascular Imaging. J Am Soc Echocardiogr. 2015;28:1 39.e14. [CrossRef]

10. Neumann FJ, Sousa-Uva M, Ahlsson A, et al. 2018 ESC/ EACTS Guidelines on myocardial revascularization. Eur Heart J. 2019;40:87-165. [CrossRef]

11. Silber S, Windecker S, Vranckx P, Serruys PW; RESOLUTE All Comers investigators. Unrestricted randomised use of two new generation drug-eluting coronary stents: 2-year patient-related versus stent-related outcomes from the RESOLUTE All Comers trial. Lancet. 2011;377:1241-7. [CrossRef]

12. Park SJ, Ahn JM, Kim YH, et al. Trial of everolimus-eluting stents or bypass surgery for coronary disease. $\mathrm{N}$ Engl J Med. 2015;372(13):1204-12. [CrossRef]

13. Chang M, Ahn JM, Lee CW, et al. Long-Term Mortality After Coronary Revascularization in Nondiabetic Patients With Multivessel Disease. J Am Coll Cardiol. 2016;68:2936. [CrossRef]

14. Waldo SW, Secemsky EA, O'Brien C, et al. Surgical ineligibility and mortality among patients with unprotected left main or multivessel coronary artery disease undergoing percutaneous coronary intervention. Circulation. 2014;130:2295-301. [CrossRef]

15. Farooq V, van Klaveren D, Steyerberg EW, et al. Anatomical and clinical characteristics to guide decision making between coronary artery bypass surgery and percutaneous coronary intervention for individual patients: development and validation of SYNTAX score II. Lancet.
2013;381:639-50. [CrossRef]

16. Nam CW, Mangiacapra F, Entjes R, et al. Functional SYNTAX score for risk assessment in multivessel coronary artery disease. J Am Coll Cardiol. 2011;58:1211-8. [CrossRef]

17. Weintraub WS, Grau-Sepulveda MV, Weiss JM, et al. Comparative effectiveness of revascularization strategies. N Engl J Med. 2012;366(16):1467-76. [CrossRef]

18. Athappan G, Chacko P, Patvardhan E, Gajulapalli RD, Tuzcu EM, Kapadia SR. Late stroke: comparison of percutaneous coronary intervention versus coronary artery bypass grafting in patients with multivessel disease and unprotected left main disease: a meta-analysis and review of literature. Stroke. 2014;45:185-93. [CrossRef]

19. van Domburg RT, Takkenberg JJ, Noordzij LJ, et al. Late outcome after stenting or coronary artery bypass surgery for the treatment of multivessel disease: a single-center matched-propensity controlled cohort study. Ann Thorac Surg. 2005;79(5):1563-9. [CrossRef]

20. McNulty EJ, Ng W, Spertus JA, et al. Surgical candidacy and selection biases in nonemergent left main stenting: implications for observational studies. JACC Cardiovasc Interv. 2011;4:1020-7. [CrossRef]

21. Singh M, Rihal CS, Lennon RJ, Spertus JA, Nair KS, Roger VL. Influence of frailty and health status on outcomes in patients with coronary disease undergoing percutaneous revascularization. Circ Cardiovasc Qual Outcomes. 2011;4:496-502. [CrossRef]

22. Bangalore S, Guo Y, Samadashvili Z, Blecker S, Xu J, Hannan EL. Everolimus-eluting stents or bypass surgery for multivessel coronary disease. N Engl J Med. 2015;372:1213-22. [CrossRef] 